\title{
The strategic value of corporate social responsibility (CSR): the present and future of its management
}

\author{
Estrella Barrio-Fraile; Ana-María Enrique-Jiménez
}

Nota: Este artículo se puede leer en español en:

http://www.elprofesionaldelainformacion.com/contenidos/2021/may/barrio-enrique_es.pdf

How to cite this article:

Barrio-Fraile, Estrella; Enrique-Jiménez, Ana-María (2021). "The strategic value of corporate social responsibility (CSR): the present and future of its management". Profesional de la información, v. 30, n. 3, e300312.

https://doi.org/10.3145/epi.2021.may.12

Manuscript received on $20^{\text {th }}$ September 2020 Accepted on $07^{\text {th }}$ December 2020

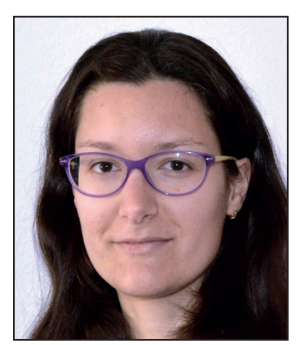

\section{Estrella Barrio-Fraile $\bowtie$ https://orcid.org/0000-0001-8047-4393 \\ Universitat Autònoma de Barcelona Facultat de Ciències de la Comunicació Carrer de la Vinya, edifici I. Campus UAB 08917 Bellaterra (Barcelona), Spain estrella.barrio@uab.cat}

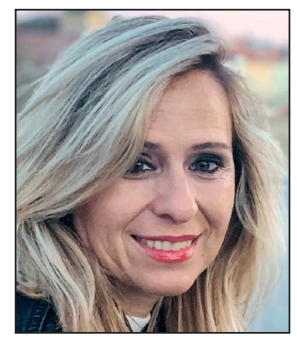

Ana-María Enrique-Jiménez https://orcid.org/0000-0001-5902-403X

Universitat Abat Oliba-CEU

Bellesguard, 30

08022 Barcelona, Spain

aenriquej@uao.es

\section{Abstract}

Corporate social responsibility (CSR) has become the central theme of many debates on the role of organizations in society in recent years. The voluntary incorporation of strategies that influence economic profitability and in turn social and environmental issues is already a reality in companies. This article has several aims: (1) to analyse whether CSR is strategic and cross-cutting for companies and whether there exists a true dialogue between companies and stakeholders; (2) to identify the functions, relationships and quality of CSR or sustainability directors; (3) to determine the main challenges for the future; (4) to reflect on the impact that Covid-19 has had on the development of CSR in businesses. The study was based on the Delphi method and employed a sample of 20 experts: 10 academics (lecturers and researchers) and 10 professionals (communication and CSR directors, and CSR and reputation consultants). The results reveal that: (1) with the exception of SMEs, CSR management in companies is strategic and cross-cutting; (2) there is no reciprocal dialogue between companies and stakeholders; (3) the functions carried out by CSR directors can be classified as analytical, strategic, tactical and communicative; (4) the most outstanding qualities of the CSR director are communication skills, deep knowledge of the company and a willingness to work as part of a team; (5) the main challenge for senior management for the future is to be more strategic; (6) Covid-19 has changed the focus in CSR areas of action and in the prioritization of stakeholders. In short, we conclude that CSR management is well rooted in companies and represents a true transformation for businesses as social entities.

\section{Keywords}

Corporate communication; Organizational communication; CSR; Corporate social responsibility; Sustainability; CSR director; Cross-cutting CSR; Strategic CSR; Stakeholder dialogue; Management; SME; Delphi; Covid-19; Pandemics; SDG.

\section{Introduction}

The scarce commercial differentiation of companies in the face of increasingly saturated audiences, together with the growing sensitivity of the public to social and environmental issues, has prompted businesses to look for other aspects -beyond the product and service offered-in order to differentiate themselves. Companies are rethinking their role as social entities, seeking a differentiating element in their identity, corporate brand and corporate social responsibility (CSR) (Villagra; López-Vázquez; Monfort, 2015). In this way, companies have stopped focusing on their commercial communication in order to focus on corporate communication and intangible values, foremost among which is CSR. CSR affects corporate reputation, "which makes its management crucial from a communication point of view" (Estanyol, 2020 , p. 1). Businesses are therefore faced with a new opportunity to respond to the demands of their audiences through ethically responsible behaviour (Barrio-Fraile; Enrique-Jiménez; Benavides-Delgado, 2017). 
CSR management is increasingly being considered a fundamental tool for companies, a strategic factor that needs to be articulated with the commitment and acceptance of businesses' governing bodies (Gálvez-Cardona, 2020; Barrio-Fraile; Enrique-Jiménez; Benavides-Delgado, 2017; Gómez-Nieto; Martínez-Domínguez, 2016; Navarro-García, 2012; Aparicio-Tovar; Valdés-De-la-Vega, 2009). This management must be global in scope and involve all departments of the company across the board (De-la-Cuesta-González; Sánchez-Paunero, 2012). As we said before, this management must not lose sight of the expectations of the public that affect or are affected by the company's activities. To try to meet the needs of the public, companies need to establish communication channels that allow a real dialogue between them and stakeholders (Babiak; Kihl, 2018; Barrio-Fraile, 2018), providing information on the effectiveness and impact of the articulated actions. Identifying, prioritizing and establishing mutual relationships with stakeholders will allow the effectiveness of CSR programs articulated by companies to be measured. This work is carried out principally in large companies under the responsibility a managerial position that is still in its infancy. The main role of the CSR director is to draw up a responsible management policy that sets out the main challenges and commitments the organization will realise through a CSR management plan (Gálvez-Cardona, 2020). And all this in a context defined by a health crisis that since 2020 has affected all socio-economic areas, a crisis in which organizations have seen their CSR programs increasingly take centre stage, becoming part of the solution to the crisis. The Deloitte and Seres report (2020) includes numerous company projects in which CSR is promoted in different areas, demonstrating how companies have deployed initiatives in order to respond to those production, health, social and economic needs that needed to be covered and that have been alleviated by their intervention.

Having discussed all the above, this study proposes the following general and secondary research objectives:

G01. To analyse whether CSR management involves a true transformation for companies as social entities oriented at all stakeholders.

SO1.1. To determine whether CSR is managed as a strategic element.

SO1.2. To determine whether CSR involves management across the whole organization.

SO1.3. To establish whether CSR management involves a true dialogue with the various stakeholders.

GO2. To identify the essential characteristics of the CSR director.

SO2.1. To specify the functions carried out by a CSR director.

SO2.2. To determine the qualities a CSR director should have.

SO2.3. To analyse the CSR director's relationship with the company's other departments.

GO3. To determine the main challenges in CSR management.

GO4. To discuss (compare opinions) whether Covid-19 has changed the prioritization of areas of CSR action and the relationship with stakeholders.

To address these objectives, we used the Delphi method, which allowed us to understand in greater depth the problem regarding knowledge that emerged from the reflections and opinions of a multidisciplinary group of Spanish CSR and sustainability experts (lecturers and researchers, communication directors, CSR directors, and CSR and reputation consultants). This study reveals that, although Covid-19 has changed the prioritization of areas of action and stakeholders, CSR management, as a strategic, cross-cutting element, is contributing to a true transformation of organizations as social entities. Similarly, the results of this study have also allowed us to establish a classification of the functions of the CSR director in analytical, strategic, tactical and communication terms.

\section{Strategic, cross-cutting CSR management}

CSR management refers to the policies, strategies and actions required to satisfy the needs of stakeholders in economic, social and environmental spheres (Barrio-Fraile; Enrique-Jiménez; Benavides-Delgado, 2017). CSR is understood as an area of strategic management for companies through which to satisfy the needs of stakeholders (Ruggiero; Cupertino, 2018). In recent decades, companies have embraced a strategic role in CSR (Kuokkanen; Sun, 2019), aligning their internal processes with their economic, social and environmental objectives (Ruggiero; Cupertino, 2018). In this way, companies have abandoned one-off philanthropy initiatives and moved to strategic CSR that involves a transformation in the company's economic activity.

This strategic approach to CSR is reflected in the definition given it by the European Commission (2011), which conceives CSR as the voluntary inclusion of social, environmental and ethical concerns by companies in the execution of their economic activity with the aim of maximizing the creation of shared value with all stakeholders. This definition involves moving away from isolated social actions to instead work together with the stakeholders in the development of a strategy aligned with the business project itself. Consequently, the strategic approach to CSR involves assuming two principles: 1 ) that the aim of CSR is to satisfy the needs of all stakeholders, and 2) that CSR must be aligned with the company's mission and purpose. 
Strategic CSR can be understood as efforts deeply rooted in the heart of the company -in its mission, purpose, corporate values and in the business strategy itself- (Barrio-Fraile; Enrique-Jiménez; Benavides-Delgado, 2017; Bocquet et al. 2019; Fontana, 2017; Gelbmann, 2010; Maignan; Ferrell; Ferrell, 2005; Rodrigo; Aqueveque; Duran, 2019; Ruggiero; Cupertino, 2018), whose aim is to address the expectations of stakeholders and meet their needs (Barrio-Fraile; Enrique-Jiménez; Benavides-Delgado, 2017; Rodrigo; Aqueveque; Duran, 2019; Ruggiero; Cupertino, 2018). Strategic CSR management provides benefits for companies in the form of building a competitive advantage (Gelbmann, 2010; Hart, 1997), improving employee engagement (Rodrigo; Aqueveque; Duran, 2019), and creating greater market and economic performance (Bocquet et al., 2019; Michelon; Boesso; Kumar, 2013).

The concept of CSR as a strategic element for companies requires comprehensive management in which all company departments are involved. We refer to the cross-cutting nature of CSR (Barrio-Fraile; Enrique-Jiménez; Benavides-Delgado, 2017; Gómez-Nieto; Martínez-Domínguez, 2016; Navarro-García, 2012; Aparicio-Tovar; Valdés-De-la-Vega, 2009). cross-cutting CSR management is defined by Barin and Michael (2010, p. 243) as

"a distinctive form of organizational configuration that crosses different functional areas, country operations, and the boundaries of the firm".

CSR must be managed in a cross-cutting manner, involving the entire organization from the general management to stakeholders and passing through each of the company's departments (De-la-Cuesta-González; Sánchez-Paunero, 2012). Barin and Michael (2010) propose a model of cross-cutting CSR management in which they note the importance of the involvement of senior managers, the involvement of the different departments of the company and the collaboration of stakeholders. In short, a cross-cutting, or integral, CSR management will make it possible to align the needs of stakeholders with the mission and business strategy of the company.

\section{Stakeholders and dialogue}

Companies have shifted from ensuring only the maximization of shareholders' benefits to managing -on the basis of CSR - the numerous varied interests of all their stakeholders (Jiang; Wong, 2016). The stakeholder theory involves the application by companies of strategies that satisfy those groups that, in some way, share interests with the company (Freeman; 1984). Therefore, CSR must involve a dynamic vision -in other words, it must gradually adapt to new issues and challenges that arise around the company and its stakeholders (Barrio-Fraile, 2018; Gelbmann, 2010). It is therefore essential to maintain a constant dialogue between companies and their stakeholders.

Dialogue between companies and their stakeholders is itself conceived as a form of CSR (Babiak; Kihl, 2018; Høvring; Andersen; Nielsen, 2018) that allows stakeholders to understand their options in relation to the company's CSR policies, providing information on the effectiveness and impact of the actions on its stakeholders (Babiak; Kihl, 2018; Barrio-Fraile, 2018), which ultimately improves the CSR management process. Companies should therefore establish two-way communication channels that allow this exchange of opinions (Monfort; Villagra; López-Vázquez, 2019). However, despite the benefits of maintaining a fluid dialogue with stakeholders, recent studies show that it is sometimes misleading and opaque, which hinders the relationship between the parties (Andersen; Høvring, 2020; Høvring; Andersen; Nielsen, 2018). In the case of social networks, which allow companies to establish two-way symmetrical communication channels (Kollat; Farache, 2017) and which could represent an important tool to connect and interact with stakeholders (IIlia et al., 2017; Saxton; Ren; Guo, 2020), they also seem to not foster a real conversation based on dialogue regarding the company's CSR (Monfort; Villagra; López-Vázquez, 2019).

\section{The CSR director}

The foundation of CSR, from its conceptualization through to professional practice, is already a reality in businesses, especially in large companies. Indeed, CSR is an increasingly formally organized field of action in organizations (Lock; Seele, 2016). Companies implement various initiatives with the aim of promoting social actions (Den-Hond; De-Bakker; Neergaard, 2007). These measures include deploying a CSR director, developing socially responsible management systems and adopting codes of conduct (Barkay, 2012). These CSR directors (also called sustainability directors) are increasingly valued by companies, who recognize their importance in the development of their sustainability and CSR plans (Osagie et al., 2016). This is demonstrated by studies by CSR professional associations that confirm that the number of executive positions related to sustainability is increasing (Davies, 2013; Weinreb Group, 2011).

This new profile represents those people who carry out the function of a CSR or sustainability director in an organization (Fernández-Fernández et al., 2014). According to the Dirse study $(2019$, p. 5), the main functions of this professional figure are to: define the CSR strategy and its influence on other policies; define and implement CSR projects; manage the relationship with stakeholders;
Developing CSR in any type of organization reflects the voluntary incorporation of those strategies that provide improvements in social welfare, protect the environment and ensure an economic profitability of the entity 
measure results; manage ethics and corporate governance; report to stakeholders; identify socioeconomic and environmental trends; analyse non-financial risks; and define and implement social action initiatives. According to this same study, the skills that a CSR director must have to carry out these functions are: being able to work in a team, managing change, building consensus, inspiring and motivating people and thinking positively, among others. In relation to qualities, the report from the Boston College Center for Corporate Citizenship (2020) highlights the ability to communicate as a fundamental skill of a CSR manager if they are to successfully carry out their professional activity. Finally, Osagie et al. (2016) note that the various skills of a CSR director must be interrelated and applied in an integrated manner.

\section{New scenarios in CSR management}

Since the beginning of the second millennium, we have been witnesses to the growing interest of companies in social and environmental issues. In 2015, the United Nations established the "Sustainable development goals" (SDGs) as part of the 2030 Agenda for Sustainable Development. This has changed what society should expect from companies in their new role as leaders towards a more sustainable world (EIAlfy et al., 2020). Therefore, the design of a CSR strategy based on SDGs is increasingly necessary (De-Lucia; Pazienza; Bartlett, 2020). Niño-Benavides and Cortés-Cortés (2018, p. 130) advocate the construction of social, civic and citizen awareness from CSR that

"must look towards new ways of guaranteeing inclusive citizenship, diverse civilities and socially-balanced business development as a social contract between citizens and organizations",

thus ensuring joint work between companies and stakeholders in the development of a fairer and more equitable society.

Since the end of 2019, our planet has been experiencing a global health crisis as a result of the Covid-19 pandemic, which has forced all countries to take emergency measures in order to minimize its spread and eradication, which is forecast to occur by the end of 2021 according to WHO (Agencias, 2020). This situation has put social structures to the test (Xifra, 2020), representing a significant change in the business environment, which could have a profound impact on CSR (He; Harris, 2020). The relationship between the private and public sector, the impact on work routines and the social response are areas of action that will be addressed through companies' CSR actions now more than ever, which will surely lead to examining in further detail the need to strengthen companies' relationships with their stakeholders.

\section{Research method}

To carry out this investigation, we employed a qualitative approach based on the Delphi method, which is a technique used in many research areas around the world (Skulmoski; Hartman; Krahn, 2007) and especially in the field of social sciences (Landeta, 2006). This method is described by Von-der-Gracht (2012, p. 1526) as a "survey technique in order to facilitate an efficient group dynamic process", since it consists of conducting anonymous and written surveys, in several stages, in which the researcher provides feedback on the group opinion after each round.

Of the various qualitative techniques, the Delphi method was chosen for its adaptability to different realities and needs (Landeta, 2006; Skulmoski; Hartman; Krahn, 2007), for its suitability in understanding problems and opportunities (Skulmoski; Hartman; Krahn, 2007), for its design flexibility, which allows for the collection of richer data that lead to a deeper understanding of the object of study (Okoli; Pawlowski, 2004) and for its prospective nature, since it allows the opinions of experts in the future to be known (Von-der-Gracht, 2012) and predictions about an area of knowledge to be made (Cabero-Almenara; Infante-Moro, 2014; Landeta, 2006; Sebastián-Morillas; Martín-Soladana; Clemente-Mediavilla, 2020; Skulmoski; Hartman; Krahn, 2007). On the other hand, one of the essential characteristics of this method is that it allows anonymity, which avoids direct confrontation between the participating experts (Landeta, 2006; Okoli; Pawlowski, 2004; Rowe; Wright, 2001).

In the Delphi method, participants must be selected for their experience in the object of study (Adler; Ziglio, 1996; ViIlagra; López-Vázquez; Monfort, 2015). In addition, a varied sample improves the quality of the results (Hussler; Muller; Rondé, 2011). Following the works of Gutiérrez-García and Recalde (2018) and Villagra, López-Vázquez and Monfort (2015), our sample includes two profiles of experts in the field of CSR: academic and professional. Regarding the size of the sample, in general between 10 and 18 participants is recommended (Okoli; Pawlowski, 2004). In our case, we employed a trial sample comprising 20 Spanish experts in CSR -10 academics and 10 professionals- with different profiles that reflect different perspectives on CSR management, which adds greater richness to the research results. The selected professionals included seven CSR or communication directors from large national and international companies operating in Spain with a workforce of more than 700 employees, two professionals from small Spanish companies in the consulting field, and a communication director from the public health sector. In the case of academics, we selected CSR experts from eight Spanish universities who had published articles on the subject from various perspectives. Table 1 shows the profile of the participants. 
Table 1. Participant profiles

\begin{tabular}{|l|l|}
\hline \multirow{2}{*}{ Profile of academics } & $\begin{array}{l}4 \text { university professors from Faculties of Communication } \\
2 \text { university professors from Business Departments } \\
3 \text { university professors from Faculties of Economic and Business Sciences } \\
1 \text { university professor from the Faculty of Legal and Social Sciences }\end{array}$ \\
\hline $\begin{array}{l}1 \text { Head of Communication of a mass-market company } \\
1 \text { Head of Communication from the public health sector } \\
1 \text { Head of Communication and CSR of a distribution company } \\
1 \text { Head of CSR of an insurance company } \\
1 \text { Head of CSR of a financial company } \\
1 \text { Head of CSR of a pharmaceutical company } \\
2 \text { Heads of CSR of an energy sector company } \\
1 \text { CSR Consultant } \\
1 \text { Reputation Consultant }\end{array}$ \\
\hline
\end{tabular}

The experts were invited by e-mail to participate in the study. The investigation took place in two waves. The first wave took place between April 27 and May 10, 2020. The questionnaire sent consisted of nine open questions. The second wave was carried out between June 8 and 21,2020. This second survey, with a questionnaire consisting of 4 open questions and 5 closed questions, was carried out based on the analysis of the responses obtained during the first wave. Twenty participants took part in the first wave, while 19 took part in the second (10 professionals and 9 academics).

Although the Delphi method was conceived as a group method whose objective was to obtain a consensus opinion, subsequent research has eliminated the obligation to reach a consensus, and thus today the Delphi method is considered a research method whose aim is to obtain a reliable group opinion (Landeta, 2006). Along these lines, the approach of Kendall et al. (1992), followed in this study, emphasizes the use of this method to compare opinions and approaches that allow alternatives or future scenarios on a specific topic to be identified.

\section{Results}

\subsection{CSR as a transforming element: strategic, cross-cutting management and dialogue with stakeholders (GO1).}

To respond to GO1, the results of its sub-objectives are presented below.

In relation to SO1.1, most of the experts $-80 \%$ of the participants- agree that CSR is being managed strategically by companies. Three arguments were used to defend this answer:

1) past philanthropic and social actions have given way to a strategic approach in which CSR is integrated into the business strategy itself;

2) CSR is no longer a communication technique, instead becoming an intangible value linked to corporate purpose and taken into account in the business strategy itself;

3) companies are systematically integrating environmental, social and ethical aspects into their business strategy, responding to the interests of stakeholders. In this way, CSR is no longer something designed make the organization look good, but an element aligned with the corporate purpose present in the high levels of decision-making and taken into account in the design of the company's business strategy itself. However, almost half of the academics associate strategic CSR management with large companies, not SMEs (see Table 2).

Table 2. Strategic CSR management

\begin{tabular}{|l|c|c|c|}
\cline { 2 - 4 } \multicolumn{1}{c|}{} & Yes & Yes (in big companies) & Depends on the business \\
\hline Professionals & $70 \%$ & $10 \%$ & $0 \%$ \\
\hline Academics & $40 \%$ & $40 \%$ & $10 \%$ \\
\hline
\end{tabular}

In the second wave, the experts were asked to assess CSR management carried out by SMEs. Virtually all the experts (95\%) agreed that, in most cases, SMEs had no strategic CSR management. The main reasons were:

1. A matter of maturity in the management style in that SMEs focus on the market and delivering results, leaving aside other aspects such as CSR management.

2. The pressure for their own survival in the short term makes them lose sight of their long-term vision, meaning they fail to implement strategic CSR plans.

3. Limited resources (money, qualified personnel and time) to carry out any reflection on and strategic implementation of CSR actions.

4. The exposure of large companies to greater legal, financial and reputational pressure to implement CSR. 
5. SMEs' lack of knowledge of CSR itself, associating it in most cases with donations and philanthropy. They therefore do not consider the benefits and value that strategic CSR management can bring to the company. This is closely related to the lack of model examples and the lack of adequate CSR management models applicable to SMEs.

The cross-cutting nature of CSR management (SO1.2) was addressed through two aspects: the areas of action in CSR matters and the departments of the organization involved in CSR management.

In relation to the first aspect, the experts coincide in noting various areas of action related to the company's own management, the consumer, the employees, the suppliers or aspects as integral as the environment that indicate true cross-cutting CSR management. Specifically, they identified six main areas of action whose degree of importance for companies was subsequently assessed by all the panel participants (on a scale of 1 to 6 , with 1 being not important and 6 being very important). The fields of action were ordered as follows: the product or service offered to the consumer; caring for the environment and actions to reduce environmental impact; corporate governance; the work environment (actions related to professional development, work-life balance, diversity, transparency, training, etc.); the supply chain (linked to suppliers and purchasing); and finally, those initiatives related to social impact aimed at society in general.

Regarding the departments involved in CSR management, as will be seen later, several departments maintain a close relationship with the CSR manager and therefore different areas of the company are involved in CSR management. Departments as important as Human Resources, Communication, Marketing, Procurement or Finance are in constant interaction with the CSR director. We can therefore speak of integral CSR management in which all the departments of the company are involved, thereby fostering the cross-cutting nature of CSR.

With respect to SO1.3, the main stakeholders with whom companies maintain dialogue include shareholders, clients, strategic partners, public administration or regulatory entities, employees, the media, suppliers, society in general, local communities and NGOs. Although clearly the stakeholders with whom companies maintain dialogue will vary according to each company, they represent a variety of groups that encompass the various audiences a company interacts with when carrying out its economic activity, which leads us again to refer to cross-cutting CSR management.

Regarding how the dialogue with stakeholders is executed, three main channels were identified: meetings (roundtables, workshops, forums), surveys and social networks. However, some of the panel experts, mainly the academics, stated that these channels are not being used as real dialogue channels between companies and stakeholders but rather that communication only flows one way.

With the aim of analysing this aspect in further detail, during the second wave of questions, the interviewees were asked to detail how these channels are used. The experts claimed that social networks are used as one-way commercial communication channels to reinforce the corporate image and not as a means of attentive, committed listening that fosters an effective dialogue with stakeholders in order to determine their needs. With regard to meetings and surveys, these are usually aimed at obtaining information from stakeholders regarding their interests and needs, which consist of a series of preconceived questions that aim to get feedback but do not encourage dialogue between the company and stakeholders.

\subsection{Characteristics of the CSR manager: functions, qualities and relationship with other departments (OG2)}

In relation to SO2.1, a list of functions emerged from the analysis of the experts' responses that we classified into four large blocks. This proposed classification of the functions and sub-functions of the CSR manager was tested during the second wave of questions, giving rise to the classification shown in Table 3.

The proposed classification includes a total of 21 functions for the CSR director, which are classified into four large functional blocks: analytical, strategic, tactical and communicative. The analytical function includes all those sub-functions related to the study of the company itself, the environment and the needs of its stakeholders. The strategic function refers to those activities related to CSR planning, its integration into the company's own strategy, its alignment with the corporate purpose and with the expectations of the stakeholders, and always thinking about innovation. The tactical function brings together all those sub-functions related to the execution of CSR itself within the company: its relationship with the other departments, the involvement of the entire company in the implementation of the plan, the collaboration of stakeholders in the execution of actions, and control of the application of the various initiatives. Finally, the communication function encompasses all those sub-functions aimed at establishing dialogue and relationships with stakeholders, raising awareness and promoting CSR and publicising the company's CSR policies.

These four large function blocks cannot be understood in isolation. For an adequate cross-cutting CSR management, it is essential that all these functions are interconnected. As an example, the analytical function of identifying the most important needs and expectations of the stakeholders cannot be understood without the communication function of establishing a dialogue with the stakeholders that allows their needs to be known.

The functions for the CSR director are classified into four functional blocks: analytical, strategic, tactical and communicative 
Table 3. Functions of the CSR director

\begin{tabular}{|l|}
\multicolumn{1}{c|}{ Analytical function } \\
\hline $\begin{array}{l}\text { To analyse the impact business decisions have on society and the } \\
\text { environment. }\end{array}$ \\
\hline To identify the most important needs and expectations of stakeholders. \\
\hline To analyse the medium and long-term trends of the environment. \\
\hline $\begin{array}{l}\text { To analyse the risks that may compromise environmental, social and } \\
\text { corporate governance sustainability. }\end{array}$ \\
\hline
\end{tabular}

\begin{tabular}{|l|}
\hline \multicolumn{1}{|c|}{ Strategic function } \\
\hline $\begin{array}{l}\text { To ensure the integration of social, environmental and ethical } \\
\text { aspects into the company's strategy. }\end{array}$ \\
\hline To promote corporate values. \\
\hline $\begin{array}{l}\text { To pursue alignment with the expectations of each group of stake- } \\
\text { holders. }\end{array}$ \\
\hline To propose CSR actions aligned with the company's purpose. \\
\hline To implement the CSR/sustainability plan. \\
\hline To innovate in the company's CSR/sustainability strategy. \\
\hline
\end{tabular}

\begin{tabular}{|l|}
\hline \multicolumn{1}{|c|}{ Tactical function } \\
\hline To work together with the company's other departments. \\
\hline $\begin{array}{l}\text { To transfer CSR to the other directors so they can implement it } \\
\text { within their areas. }\end{array}$ \\
\hline $\begin{array}{l}\text { To get all company departments involved in the planning and } \\
\text { implementation of CSR. }\end{array}$ \\
\hline To get stakeholders involved in the company's social development. \\
\hline To implement CSR initiatives and actions. \\
\hline To monitor and evaluate the application of CSR policies. \\
\hline
\end{tabular}

\section{Communicative function}

To raise awareness about CSR and promote CSR among internal and external audiences.

To establish dialogue with stakeholders.

To establish institutional relationships with regulators, institutions and investors.

To report on/publish the progress of the CSR plan to internal and external audiences through means such as the CSR report or the corporate website.

To represent the company in CSR forums and events.

Regarding the qualities that a CSR director must have (SO2.2), in the first round, the experts freely indicated the qualities that a CSR manager should have. In the second round, these qualities were evaluated on a scale of 1 to 6 ( 1 being not important and 6, very important). The six most outstanding qualities scored with a high degree of importance were: communication skills (in terms of listening and dialogue); having exhaustive knowledge of the company and its environment; the ability to foster teamwork and establish synergies between all departments; having a strategic vision of the business; showing empathy; and having the ability to lead and influence the organization.

Another aspect worth commenting upon is that even having obtained a high importance average in all the qualities, the professionals scored them with a greater degree of importance than the academics possibly because professionals experience the need to develop or work on them directly in their daily work (Table 4).

Table 4. Importance of the qualities of the CSR director

\begin{tabular}{|c|c|c|c|}
\hline Qualities & $\begin{array}{c}\text { Average all } \\
\text { experts }\end{array}$ & $\begin{array}{c}\text { Average } \\
\text { academics }\end{array}$ & $\begin{array}{c}\text { Average } \\
\text { professionals }\end{array}$ \\
\hline Communication (dialogue and listening) & 5.7 & 5.6 & 5.9 \\
\hline Deep knowledge of the company and the environment & 5.6 & 5.3 & 5.8 \\
\hline Willingness to work as part of a team and to collaborate with all departments & 5.6 & 5.2 & 5.9 \\
\hline Strategic vision & 5.6 & 5.1 & 6.0 \\
\hline Empathy & 5.5 & 5.1 & 5.9 \\
\hline Capacity to influence and lead & 5.5 & 5.1 & 5.8 \\
\hline Positivity & 5.4 & 5.0 & 5.8 \\
\hline Negotiation skills & 5.4 & 5.2 & 5.6 \\
\hline Resilience & 5.4 & 4.9 & 5.8 \\
\hline Analytical skills & 5.3 & 5.1 & 5.5 \\
\hline Perseverance & 5.3 & 4.9 & 5.6 \\
\hline Flexibility & 5.3 & 4.9 & 5.6 \\
\hline Results oriented & 5.0 & 4.4 & 5.5 \\
\hline Entrepreneurial spirit & 4.8 & 4.4 & 5.2 \\
\hline
\end{tabular}

With regard to the relationship of the CSR manager with the organization's departments (SO2.3), in general terms, the cross-cutting nature of his/her function has already been highlighted, arguing that the CSR director interacts with all the 
company's departments. Five departments were identified by the experts as those having greater interaction with the CSR manager: Human Resources, Communication, Sales/Marketing, Purchasing and Financial.

During the first wave, various experts stated that the relationship the CSR director maintains with the company's other departments is complex. In order to investigate this matter further, in the second wave the experts were provided with a list of possible reasons for this complex relationship to evaluate. A five-point Likert scale was used. As can be seen in Table 5, the only consensus was in recognizing that the CSR director must get other areas involved in the implementation of the CSR strategy as a reason for the complex relationship between the CSR manager and other departments, since its execution depends largely on the other departments.

Regarding the other factors analysed, we observed a range of opinions. Only around half of the experts agree with these reasons. The factors causing discrepancy among experts included: the complexity of finding a balance between different business priorities; the high burden of reporting the CSR director needs to undertake, resulting in him/her being perceived as some sort of auditor who is always requesting information; that the work of the CSR director focuses on global company issues, while other directors focus on particular issues in their areas; that the CSR director is viewed as an outsider who creates more work (Table 5).

Table 5. Reasons for the complexity in the relationship between the CSR director and other departments

\begin{tabular}{|c|c|c|c|c|c|}
\hline & $\begin{array}{l}\text { Totally } \\
\text { disagree }\end{array}$ & $\begin{array}{l}\text { Strongly } \\
\text { disagree }\end{array}$ & $\begin{array}{l}\text { Neither agree } \\
\text { nor disagree }\end{array}$ & $\begin{array}{l}\text { Strongly } \\
\text { agree }\end{array}$ & Totally agree \\
\hline $\begin{array}{l}\text { The CSR director needs to get other departments invol- } \\
\text { ved in the implementation of the CSR strategy, since its } \\
\text { execution depends largely on the other departments. }\end{array}$ & $0.00 \%$ & $0.00 \%$ & $0.00 \%$ & $36.84 \%$ & $63.16 \%$ \\
\hline $\begin{array}{l}\text { It is difficult to find the balance between different busi- } \\
\text { ness priorities. }\end{array}$ & $0.00 \%$ & $15.79 \%$ & $31.58 \%$ & $26.32 \%$ & $26.32 \%$ \\
\hline $\begin{array}{l}\text { His/her high reporting burden means the CSR director is } \\
\text { perceived as a form of auditor who is always requesting } \\
\text { information. }\end{array}$ & $0.00 \%$ & $26.32 \%$ & $26.32 \%$ & $31.58 \%$ & $15.79 \%$ \\
\hline $\begin{array}{l}\text { The CSR director's work focuses on global company } \\
\text { issues, while the other directors focus on particular issues } \\
\text { in their areas. }\end{array}$ & $10.53 \%$ & $15.79 \%$ & $21.05 \%$ & $36.84 \%$ & $15.79 \%$ \\
\hline $\begin{array}{l}\text { The CSR director is perceived as an outsider who creates } \\
\text { more work. }\end{array}$ & $5.26 \%$ & $26.32 \%$ & $21.05 \%$ & $47.37 \%$ & $0.00 \%$ \\
\hline
\end{tabular}

\subsection{Future challenges in CSR management (GO3)}

In this section we address the future key challenges CSR directors need to take into account in order to define lines of action that allow them to achieve their CSR objectives. The challenges the experts identified in the first wave and prioritized in the second wave are shown in Table 6.

1. Being more strategic for senior management, integrating sustainability policies and a culture of ethics into the management of the company. In this way, the company will define guidelines outlining its commitment to society and its environment. These actions must be promoted from the company's highest authority and ensure that they are implemented throughout its value chain.

2. Providing value in order for companies to be more credible. The public needs to understand that carrying out CSR is an act of real commitment by the company towards society and is not related in any way with greenwashing actions.

3. Measuring the impact of CSR and how it benefits the company's profit and loss statement. Establishing mechanisms and standards that allow the real contribution of CSR strategies to be measured is one of the main tasks of CSR directors in their quest to demonstrate that CSR is an investment and not an expense.

4. Transparency, especially in terms of communication. Dialogue with stakeholders must be based on transparency, on explaining what the company really does in terms of CSR, but not by focusing on the organization itself but on how it is solving the problem or is helping to improve the world around us.

5. Encouraging dialogue with stakeholders by generating new ways of stimulating communication with them. It will be important to implement channels that allow two-way communication and listening to society's demands.

6. Complying with SDGs (2030 agenda). Businesses, in their role as agents of change, are essential to comply with the SDGs established by the United Nations with the aim of promoting a more just and equitable world. Gender equality, the reduction of inequalities, health, well-being or climate action are examples of SDGs being considered in companies' CSR strategies.

Following Covid-19, companies prioritized actions related to the work environment 
Table 6. Prioritization of future challenges in CSR management

\begin{tabular}{|c|c|c|c|c|c|c|c|c|c|c|c|c|}
\hline & 1 & 2 & 3 & 4 & 5 & 6 & 7 & 8 & 9 & 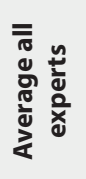 & 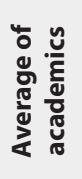 & 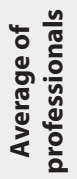 \\
\hline \multirow{2}{*}{$\begin{array}{l}\text { Managing CSR more } \\
\text { strategically for senior } \\
\text { management. }\end{array}$} & $10.53 \%$ & $5.26 \%$ & $5.26 \%$ & $15.79 \%$ & $5.26 \%$ & $0.00 \%$ & $15.79 \%$ & $5.26 \%$ & $36.84 \%$ & \multirow{2}{*}{6.0} & \multirow{2}{*}{5.4} & \multirow{2}{*}{6.4} \\
\hline & 2 & 1 & 1 & 3 & 1 & 0 & 3 & 1 & 7 & & & \\
\hline \multirow{2}{*}{$\begin{array}{l}\text { Contributing value to make } \\
\text { companies more credible. }\end{array}$} & $5.26 \%$ & $5.26 \%$ & $10.53 \%$ & $15.79 \%$ & $15.79 \%$ & $5.26 \%$ & $5.26 \%$ & $15.79 \%$ & $21.05 \%$ & \multirow{2}{*}{5.8} & \multirow{2}{*}{5.7} & \multirow{2}{*}{6.0} \\
\hline & 1 & 1 & 2 & 3 & 3 & 1 & 1 & 3 & 4 & & & \\
\hline \multirow{2}{*}{$\begin{array}{l}\text { Measuring the impact of } \\
\text { CSR. }\end{array}$} & $0.00 \%$ & $26.32 \%$ & $5.26 \%$ & $5.26 \%$ & $15.79 \%$ & $15.79 \%$ & $0.00 \%$ & $31.58 \%$ & $0.00 \%$ & \multirow{2}{*}{5.3} & \multirow{2}{*}{5.9} & \multirow{2}{*}{4.8} \\
\hline & 0 & 5 & 1 & 1 & 3 & 3 & 0 & 6 & 0 & & & \\
\hline \multirow{2}{*}{$\begin{array}{l}\text { Transparency, especially in } \\
\text { communication issues. }\end{array}$} & $0.00 \%$ & $15.79 \%$ & $10.53 \%$ & $5.26 \%$ & $21.05 \%$ & $5.26 \%$ & $21.05 \%$ & $15.79 \%$ & $5.26 \%$ & \multirow{2}{*}{5.3} & \multirow{2}{*}{5.0} & \multirow{2}{*}{5.6} \\
\hline & 0 & 3 & 2 & 1 & 4 & 1 & 4 & 3 & 1 & & & \\
\hline \multirow{2}{*}{$\begin{array}{l}\text { Promoting dialogue with } \\
\text { stakeholders. }\end{array}$} & $10.53 \%$ & $5.26 \%$ & $5.26 \%$ & $10.53 \%$ & $15.79 \%$ & $15.79 \%$ & $26.32 \%$ & $5.26 \%$ & $5.26 \%$ & \multirow{2}{*}{5.2} & \multirow{2}{*}{4.9} & \multirow{2}{*}{5.6} \\
\hline & 2 & 1 & 1 & 2 & 3 & 3 & 5 & 1 & 1 & & & \\
\hline \multirow{2}{*}{$\begin{array}{l}\text { Compliance with SDGs } \\
\text { (2030 agenda). }\end{array}$} & $10.53 \%$ & $5.26 \%$ & $10.53 \%$ & $26.32 \%$ & $10.53 \%$ & $21.05 \%$ & $0.00 \%$ & $10.53 \%$ & $5.26 \%$ & \multirow{2}{*}{4.7} & \multirow{2}{*}{4.2} & \multirow{2}{*}{5.1} \\
\hline & 2 & 1 & 2 & 5 & 2 & 4 & 0 & 2 & 1 & & & \\
\hline \multirow{2}{*}{$\begin{array}{l}\text { Promoting more alliances } \\
\text { with other public or private } \\
\text { organizations. }\end{array}$} & $5.26 \%$ & $21.05 \%$ & $21.05 \%$ & $0.00 \%$ & $5.26 \%$ & $15.79 \%$ & $21.05 \%$ & $0.00 \%$ & $10.53 \%$ & \multirow{2}{*}{4.6} & \multirow{2}{*}{5.1} & \multirow{2}{*}{4.1} \\
\hline & 1 & 4 & 4 & 0 & 1 & 3 & 4 & 0 & 2 & & & \\
\hline \multirow{2}{*}{$\begin{array}{l}\text { Expanding areas of action, } \\
\text { prioritizing social challen- } \\
\text { ges. }\end{array}$} & $26.32 \%$ & $5.26 \%$ & $15.79 \%$ & $15.79 \%$ & $5.26 \%$ & $15.79 \%$ & $5.26 \%$ & $5.26 \%$ & $5.26 \%$ & \multirow{2}{*}{4.1} & \multirow{2}{*}{3.9} & \multirow{2}{*}{4.3} \\
\hline & 5 & 1 & 3 & 3 & 1 & 3 & 1 & 1 & 1 & & & \\
\hline \multirow{2}{*}{$\begin{array}{l}\text { Promoting new technolo- } \\
\text { gies in CSR management. }\end{array}$} & $31.58 \%$ & $10.53 \%$ & $10.53 \%$ & $10.53 \%$ & $5.26 \%$ & $5.26 \%$ & $5.26 \%$ & $10.53 \%$ & $10.53 \%$ & ( & 10 & 27 \\
\hline & 6 & 2 & 2 & 2 & 1 & 1 & 1 & 2 & 2 & & 4.9 & 3.2 \\
\hline
\end{tabular}

$1=$ the least important, $9=$ the most important

7. Expanding areas of action, prioritizing social challenges. This challenge has gained momentum, especially in the post-Covid-19 era. Issues such as support for society and local communities or the health and safety of employees have become a priority, to the detriment of other initiatives that impact other stakeholders. Today more than ever, citizens and domestic audiences require greater care given their degree of vulnerability, which has been evidenced by the pandemic.

8. Fostering more alliances with other public or private organizations. The management of projects and social activities today requires alliances and comprehensive strategies that represent a win-win situation for all partners.

9. Promoting new technologies as opportunities to better manage the various areas of CSR, since they will affect our daily life and the future of our way of working.

Comparing the responses of the academics and professionals, it is notable that the academics identify measuring the impact of CSR and promoting new technologies as being the greatest challenges. This may be due to the fact that, for the professionals, measuring the impact of CSR or promoting new technologies are issues that are already part of their daily reality and therefore do not perceive them as a challenge to be faced in the future. The latter is only a hypothesis and should be confirmed in future research.

\subsection{Impact of Covid-19 on areas of CSR action and on the relationship with stakeholders (GO4).}

With regard to $\mathrm{GO} 4$, in the first wave, the experts stated that following the impact of Covid-19 they did not believe there had been substantial changes in terms of areas of action but that perhaps the focus would be more on social issues. In the second wave we therefore asked them to rank in order of importance for companies the areas of CSR action before and after Covid-19 (using a scale of 1 to 6, 1 being not important and 6, very important). The results are shown in Table 7 . 
In general, the experts noted a trend towards more social areas of action, highlighting a growing importance for the work environment and social action. Examining in detail it can be seen that all areas of CSR action have undergone changes in their positions. The first area of action in the pre-Covid-19 era, the product or service offered to the consumer, fell to second place following Covid-19, with priority given to the work environment. This finding is quite significant, since Covid-19 has effectively impacted on work routines, promoting teleworking in those businesses that could implement it or implementing health and safety protocols so that employees can carry out their work with the full guarantee of not being infected. Social action has gone from being the last field of action to occupying third place following Covid-19. Businesses are understood to have opted to address issues that affect society in general and thus show this facet of responsibility and commitment to people. It is curious that this involvement in social issues is not shown in the environment, a field of action that prior to Covid-19 was second in importance and has now moved to penultimate position. The same has occurred with corporate governance, which was the third area of action in the pre-Covid-19 era but is now last.

Regarding dialogue with stakeholders and the importance companies give to establishing relationships and communication with them, they were also asked to assess its importance before and after Covid-19 (Table 8).

In general, an upward trend can be observed in the dialogue between businesses and stakeholders after the emergence of Covid-19, with local communities having seen their relationship with businesses intensified more compared with the pre-Covid-19 era, probably due to the social emergency situation caused by Covid-19. In more detail, Table 8 shows that the top two stakeholders (shareholders and clients) have not changed their positions in the pre- and post-Covid-19 eras. The changes take place from third place, strategic partners, which after Covid-19 moved to fifth place. It should be noted that this change was, in particular, a result of the academics' evaluation, since the professionals valued strategic partners as very important, very close to the value shareholders and clients place on them. As a result of this change, public administration moved up one position to third place, followed by employees. These two stakeholders have been crucial following the impact of Covid-19. Indeed, the relationship between businesses and public administration has become more important than ever, since safety and hygiene protocols must be applied rigorously. Employees also become an audience with whom communication channels must be established in order to ensure the continuity of business activity with full guarantees. Society in general and the local community also moved up in the ranking. This result corresponds to the results shown above where we saw how the sphere of social action gained greater importance. The media and suppliers have also been affected in the table, occupying the last positions. NGOs remain the least important stakeholder.

\section{Discussion}

This study examines various aspects of corporate social responsibility (CSR), considered a transformative element for companies and which requires the figure of a director with specific skills to face the main future challenges involved in its management, especially following the Covid-19 pandemic.

Regarding GO1, the experts' responses indicate the existence of a CSR management rooted in businesses that represents a true transformation for companies as social entities oriented at all stakeholders. This can be observed in three aspects:

Firstly, the experts noted that CSR has evolved from being a one-off philanthropic or social action to becoming an intangible value linked to the business's mission, purpose and strategy. Furthermore, it is being managed strategically, integrating environmental, social and ethical aspects into the business strategy itself in order to respond to stakeholders' interests. These results coincide with the results previously published by various authors who state that CSR arises from the identity of the organization -mission, purpose, values and business strategy- (Barrio-Fraile; Enrique-Jimé- 
nez; Benavides-Delgado, 2017; Bocquet et al., 2019; Fontana, 2017; Gelbmann, 2010; Maignan; Ferrell; Ferrell, 2005; Rodrigo; Aqueveque; Duran, 2019; Ruggiero; Cupertino, 2018) and that it aims to satisfy the needs of all stakeholders (Barrio-Fraile; Enrique-Jiménez; Benavides-Delgado, 2017; Rodrigo; Aqueveque; Duran, 2019; Ruggiero; Cupertino, 2018). Therefore, the two principles set out in the theoretical framework that support the existence of a strategic approach to CSR by companies are confirmed: alignment with the corporate mission and purpose and satisfying the needs of stakeholders.

Secondly, the results indicate a cross-cutting CSR management in which, following the proposals of Barin and Michael (2010) and De-la-Cuesta-González and Sánchez-Paunero (2012), all company departments are involved. The experts coincided in highlighting areas of CSR action related to all areas of the company: the product or service offered to the consumer; caring for the environment and actions to reduce environmental impact; corporate governance; the work environment. They also highlighted the close relationship between the CSR director and the company's other departments, implying that they are all involved in CSR management.

Thirdly, businesses maintain a dialogue with their stakeholders, foremost among which are: shareholders, clients, strategic partners, public administration or regulatory bodies, employees, the media, suppliers, society in general, local communities and NGOs. The channels used for this are mainly meetings, surveys and social networks.

Despite all this, the experts highlighted two exceptions. On the one hand, it seems that strategic CSR management is limited to large companies, while in SMEs CSR is not managed as a strategic element. Several reasons were indicated, ranging from a question of maturity in the management style, limited resources, or pressure for the company's own survival, although ultimately, all of them arise from a lack of knowledge by SMEs of the concept of CSR itself, which they associate with philanthropic initiatives, which shows the lack of CSR references or management models for SMEs. This fact requires special attention, since 99.8\% (Bartolomé, 2019) of the European industrial fabric is made up of small companies. We believe therefore that this avenue should be explored further in the future. However, as Andersen and Høvring (2020) and Høvring, Andersen and Nielsen (2018) note, the results indicate a lack of true two-way communication channels between companies and stakeholders that promote a transparent, sincere dialogue based on reciprocity. With regard to social networks, which could represent a powerful two-way communication tool to engage stakeholders, the experts point out that they are not being used as a channel to promote real dialogue between companies and stakeholders, but rather are used as a means to report on the CSR carried out by companies, a result that coincides with the findings of Monfort, Villagra and López-Vázquez (2019).

This aspect requires special attention, since the establishment of a true constant dialogue with stakeholders is of vital importance to determine their needs, and therefore, for adequate CSR management.

\section{Strategic CSR management is limited to large companies, while in SMEs CSR is not managed as a strategic element}

Regarding GO2, the results of this study have made it possible to outline the CSR or sustainability director: the functions $\mathrm{s} /$ he performs, the qualities that $\mathrm{s} /$ he must have, and the relationship s/he maintains with the company's other departments. Regarding the functions carried out by the CSR director, the proposed classification into four large functional blocks stands out: analytical function, strategic function, tactical function and communication function. This shows the integral, cross-cutting role the CSR director must have in order to carry out his/her work. It is also interesting to note that in order to achieve an adequate and truly cross-cutting management in the organization, all these functions must be interconnected, a finding that coincides with the results of Osagie et al. (2016). Regarding the qualities a CSR director must have, the experts highlighted in first place the ability to communicate, which coincides with the results of the study carried out by the Boston College Center for Corporate Citizenship (2020), followed by a deep knowledge of the company and its environment, the ability to foster teamwork and establish synergies between departments, a strategic vision of the business, empathy and the ability to lead and influence the organization, all of which are closely related to the development of the four large functional blocks of these professionals. Regarding the relationship of the CSR director with the other areas, s/he maintains a relationship with all the company's departments, thus promoting the cross-cutting nature of CSR. Achieving this involvement of other departments in the execution of the CSR plan is precisely why it is considered the main reason for the complex relationship established between the CSR department and the company's other departments. Finally, it is interesting to note on this objective that the four main functional blocks (analytical, strategic, tactical and communicative) are closely linked to a true transformation for companies that understand CSR as a strategic, cross-cutting element in which dialogue with stakeholders is vital.

Regarding GO3, which was to determine the main challenges in CSR management, the experts indicated the following lines of action, from highest to lowest importance: being more strategic for senior management; adding value to make companies more credible; trying to measure the impact of CSR on the company; being more transparent; fostering true dialogue with stakeholders; complying with SDGs (2030 Agenda); promoting alliances with other organizations; expanding the areas of action, prioritizing social challenges; and finally, promoting the technological transformation of companies. These results reflect how CSR management is being oriented to be a transformative element in companies, since CSR is considered a strategic component for senior management and a cross-cutting one in businesses that adds value to the organization by promoting transparency and dialogue with stakeholders. In this regard, the results obtained are 
in line with those of Niño-Benavides and Cortés-Cortés (2018), who advocate a transformation of companies through their CSR as active actors in social welfare. However, it is striking that compliance with the 2030 Agenda is not among the top five future challenges for CSR directors, which contrasts with authors such as De-Lucia, Pazienza and Bartlett (2020), who defend a CSR strategy based on SDGs. This finding may be due to the fact that SDGs are already currently the pillars of company CSR plans. However, this hypothesis needs to be tested in future investigations.

The aim of GO4 was to determine whether the incursion of Covid-19 into our society has modified companies' prioritization of CSR areas of action, as well as the relationship they have with their stakeholders. After analysing the results, we can conclude that, according to the experts, there has indeed been a change in the prioritization of areas of action. Companies, when deploying their CSR strategies following the pandemic, focused on issues related to the work environment. The Covid-19 health crisis has affected work routines, promoting remote working in those organizations that could implement it or implementing health and safety protocols so that employees can carry out their work under total guarantee of not being infected. Social action also gains importance and more so than in the pre-Covid-19 era. Businesses are understood to have chosen to address issues that affect society in general and thus show this facet of responsibility and commitment to people. This claim is in line with the results obtained in the report on the social impact of companies in the face of Covid-19 (Deloitte; Seres, 2020), which show that 78\% of the CSR initiatives analysed correspond to issues that have an impact on social welfare, focusing on issues such as health, care and coverage of social needs or education. The environment, a paramount area, has been somewhat temporarily neglected as a result of the pandemic, especially in its early phase, demonstrating that some companies wished to prioritize and address these social urgencies to the detriment of environmental issues. However, we believe that in the medium- to long-term climate change and its impact on our ecosystem will continue to be a fundamental aspect in terms of CSR and sustainability. Regarding the relationship with stakeholders, the changes have not been so significant. Shareholders and customers continue to be the priority audiences for companies. Public administration and local communities are the stakeholders that have seen dialogue with businesses most intensified following Covid-19, probably due to the social emergency situation caused by the pandemic and to their fundamental role in establishing and complying with regulations and protocols that minimize the spread of the virus. However, the most remarkable finding at this point is the increase in the dialogue between businesses and stakeholders following the pandemic. Together, these facts indicate, as predicted by He and Harris (2020), that Covid-19 has affected the CSR of companies, although it is still difficult to diagnose the depth of these changes.

\section{Conclusions}

This study highlights the strategic value of CSR for Spanish companies, especially large companies, and shows its roots in corporate purpose. This consideration of CSR as a strategic element is demonstrated insofar as these organizations have stopped articulating specific actions, instead proposing CSR policies that are integrated into the company's own strategy. CSR management is characterized by being cross-cutting, by involving each and every one of the company's departments, especially HR, Communication and Marketing. The identification and prioritization of stakeholders is essential to establishing commitments with them. However, this study has revealed that no real dialogue exists between companies and stakeholders. Companies know that it is necessary to open communication channels in order to determine stakeholders' expectations and perceptions of articulated CSR initiatives, but in practice, these tools become mere dissemination channels and not media that allow two-way communication between companies and their audiences.

On the other hand, a way to identify and classify the functions of the CSR director has been proposed, being categorized as analytical, strategic, tactical and communicative. This classification allows us to cover the main responsibilities that CSR directors carry out in their daily activities. This classification clarifies their competences and serves as a reference for academic and professional fields, and as a starting point for future research that enables theoretical and practical comparisons.

Finally, although as mentioned above we can discuss the strategic value of CSR, one of the challenges facing CSR management is that it is considered and therefore consolidated as a form of strategic management from the top governing bodies. What has been demonstrated during the Covid-19 pandemic is that CSR has gained greater prominence than ever, forcing companies to focus on social welfare and primary needs such as safety, health, and food.

The present investigation is not without limitations. The first relates to the geographical scope of the study, which was carried out in Spain. It would therefore be interesting to replicate this study in other countries, which would allow a comparison of the state of CSR in different parts of the world. The second and main limitation of the study relates to the Delphi method itself, a qualitative research technique that, despite having provided in-depth knowledge about CSR, does not allow the results to be generalized. Therefore, new avenues of research open up that would focus on obtaining representative results through quantitative studies that would allow researchers to analyse what form CSR management takes on in companies and the professional profile that manages it.

The implementation of CSR in any type of organization reflects the voluntary incorporation of those strategies that bring about improvements in social welfare, protect the environment and ensure the business's economic profitability 
Despite the limitations raised, the results of this study represent an advance in the study of CSR management in organizations and provide the basis for the development of future research. In this regard, it is worth highlighting the possibility of carrying out a quantitative study, and therefore of having a significant sample of companies, to verify the findings of this article, especially those issues related to the transformative role of CSR and the use of channels that promote dialogue between companies and stakeholders. Another potential avenue would be to carry out a representative survey of CSR directors that would allow the proposed functions of this professional profile to be validated. It would also be interesting to carry out a study aimed at analysing CSR management in SMEs, a type of company forgotten in research but tremendously important for the European economic fabric.

\section{References}

Adler, Michael; Ziglio, Erio (1996). Gazing into the oracle: Delphi method and its application to social policy and public health. Jessica Kingsley Publishers. ISBN: 9781853021046

Agencias (2020). "La OMS pone fecha al control de la pandemia: en menos de dos años". La vanguardia, 21 agosto. https://www.lavanguardia.com/vida/20200821/482924968108/oms-fin-pandemia-dos-anos.html

Andersen, Sophie-Esmann; Høvring, Christiane-Marie (2020). "CSR stakeholder dialogue in disguise: Hypocrisy in story performances". Journal of business research, v. 114, pp. 421-435.

https://doi.org/10.1016/j.jbusres.2019.08.030

Aparicio-Tovar, Joaquín; Valdés-De-la-Vega, Berta (2009). "Sobre el concepto de responsabilidad social de las empresas. Un análisis europeo comparado". Cuadernos de relaciones laborales, v. 27, n. 1, pp. 53-75.

http://revistas.ucm.es/index.php/CRLA/article/view/CRLA0909120053A

Babiak, Kathy; Kihl, Lisa A. (2018). "A case study of stakeholder dialogue in professional sport: An example of CSR engagement". Business and society review, v. 123, n. 1, pp. 119-149.

https://doi.org/10.1111/basr.12137

Barin, Luciano; Michael, Dirk (2010). “How do leading retail MNCs leverage CSR globally? Insights from Brazil”. Journal of business ethics, v. 91, pp. 243-263.

https://doi.org/10.1007/s10551-010-0617-8

Barkay, Tamar (2012). "Employee volunteering: soul, body and CSR". Social responsibility journal, v. 8, n. 1, pp. 48-62. https://doi.org/10.1108/17471111211196566

Barrio-Fraile, Estrella (2018). "La gestión de la responsabilidad social corporativa: Propuesta de un modelo teórico". Questiones publicitarias, n. 22, pp. 59-68.

https://doi.org/10.5565/rev/qp.311

Barrio-Fraile, Estrella; Enrique-Jiménez, Ana-María; Benavides-Delgado, Juan (2017). "The CSR management process. Case study". Revista latina de comunicación social, n. 72, pp. 1063-1084.

http://www.revistalatinacs.org/072paper/1208/58es.html

Bartolomé, Laura (2019). "Las pymes ya representan el 99,8\% de empresas europeas". El economista, 19 febrero. https://www.eleconomista.es/gestion-empresarial/noticias/9709265/02/19/Las-pymes-ya-representan-el-998-deempresas-europeas.html

Bocquet, Rachel; Le-Bas, Christian; Mothe, Caroline; Poussing, Nicolas (2019). "Strategic CSR for innovation in SMEs: Does diversity matter?". Long range plannning, v. 52, n. 6, 101913.

https://doi.org/10.1016/j.Irp.2019.101913

Boston College Center for Corporate Citizenship (2020). Profile of the Professionals 2020 Executive Summary. https://bc-ccc.uberflip.com/i/1257533-profile-of-the-professionals-2020-executive-summary

Cabero-Almenara, Julio; Infante-Moro, Alfonso (2014). “Empleo del método Delphi y su empleo en la investigación en comunicación y educación". Edutec. Revista electrónica de tecnología educativa, n. 48.

https://doi.org/10.21556/edutec.2014.48.187

De-la-Cuesta-González, Marta; Sánchez-Paunero, David (2012). Responsabilidad social universitaria 2.0. Oleiros (La Coruña): Netbiblo, ISBN: 9788497456555

Deloitte; Seres (2020). Informe del impacto social de las empresas frente a la Covid-19. Deloitte Consulting, S.L.U. y Fundación Seres.

https://www.fundacionseres.org/Lists/Informes/Attachments/1134/Fundacion\%20SERES\%20-\%20Informe\%20 Impacto\%20Covid_19.pdf

De-Lucia, Caterina; Pazienza, Pasquale; Bartlett, Mark (2020). “Does good ESG lead to better financial performances by firms? Machine learning and logistic regression models of public enterprises in Europe". Sustainability, v. 12, n. 13, 5317. https://doi.org/10.3390/su12135317 
Dirse (2019). II Estudio de la función dirse en la empresa española. Madrid: Asociación Española de Directivos de Responsabilidad Social (Dirse).

http://www.dirse.es/wp-content/uploads/2019/05/190509-DIRSE_Estado-de-la-profesion-2019_LARGO_V3.pdf

ElAlfy, Amr; Palaschuk, Nicholas; El-Bassiouny, Dina; Wilson, Jeffrey; Weber, Olaf (2020). "Scoping the evolution of corporate social responsibility (CSR) research in the sustainable development goals (SDGs) era". Sustainability, v. 12, n. $14,5544$.

https://doi.org/10.3390/su12145544

Estanyol, Elisenda (2020). "Communicating corporate social responsibility (CSR): An analysis of the most award-winning campaigns of 2018". Profesional de la información, v. 29, n. 3, e290334.

https://doi.org/10.3145/epi.2020.may.34

European Commission (2011). Communication from the commission to the European parliament, the council, the european economic and social committee and the committee of the regions: a renewed EU strategy 2011-14 for corporate social responsibility. Brussels: European Commission.

https://op.europa.eu/en/publication-detail/-/publication/ae5ada03-0dc3-48f8-9a32-0460e65ba7ed

Fernández-Fernández, José-Luis; Benavides-Delgado, Juan; García-Polo, Roberto; Sánchez-Mora-Moreno, Fernando (2014). Repensar la responsabilidad social. Una mirada desde los dirse. Madrid: Asociación Española de Directivos de Responsabilidad Social (Dirse). ISBN: 9788469716458

Fontana, Enrico (2017). "Strategic CSR: a panacea for profit and altruism? An empirical study among executives in the Bangladeshi RMG supply chain". European business review, v. 29, n. 3, pp. 304-319.

https://doi.org/10.1108/EBR-12-2015-0172

Freeman, R. Edward (1984). Strategic management. A stakeholder approach. Boston: Pitman. ISBN: 0273019139

Gálvez-Cardona, María-José (2020). “Gestión de la responsabilidad social corporativa”. En: Valbuena-García, Esther; Montfort-De-Bedoya, Abel. Ética, deontología y responsabilidad social empresarial, pp. 203-217. Madrid: Esic Editorial. ISBN: 9788418415104

Garmendia-Martínez, José-Antonio (2009). “Qué decir y para qué sirve la responsabilidad social corporativa”. En: Almagro, Juan-José; Garmendia, José-Antonio; De-la-Torre, Isabel. Responsabilidad social. Una reflexión global sobre la RSE. Madrid: Prentice Hall. ISBN: 9788483226391

Gelbmann, Ulrike (2010). "Establishing strategic CSR in SMEs: an Austrian CSR quality seal to substantiate the strategic CSR performance". Sustainable development, v. 18, n. 2, pp. 90-98.

https://doi.org/10.1002/sd.448

Gómez-Nieto, Begoña; Martínez-Domínguez, Rocío (2016). "Los valores éticos en la responsabilidad social corporativa”. Anagramas: Rumbos y sentidos de la comunicación, v. 14, n. 28, pp. 33-50.

https://dialnet.unirioja.es/servlet/articulo?codigo $=5505422$

Davies, John (2013). State of the profession. GreenBiz Group.

https://www.greenbiz.com/article/state-profession-2013

Den-Hond, Frank; De-Bakker, Frank G. A.; Neergaard, Peter (2007). "Introduction”. In: Den-Hond, F.; De-Bakker, F. G. A.; Neergaard, P. Managing corporate social responsibility in action: Talking, doing, measuring. Aldershot: Ashgate, pp. 1-12. ISBN: 97800754647218

Gutiérrez-García, Elena; Recalde, Mónica (2018). “Portraying tomorrow's professionals: Delphi study on strategic communication capabilities in Spain". Anàlisi, n. 59, pp. 139-156.

https://doi.org/10.5565/rev/analisi.3153

Hart, Stuart L. (1997). "Beyond greening: strategies for a sustainable world". Harvard business review, v. 75, n. 1, pp. 67-76.

He, Hongwei; Harris, Lloyd (2020). "The impact of Covid-19 pandemic on corporate social responsibility and marketing philosophy". Journal of business research, v. 116, pp. 176-182.

https://doi.org/10.1016/j.jbusres.2020.05.030

Høvring, Christiane-Marie; Andersen, Sophie-Esmann; Nielsen, Anne-Elerup (2018). "Discursive tensions in CSR multi-stakeholder dialogue: A Foucauldian perspective". Journal of business ethics, v. 152, pp. 627-645.

https://doi.org/10.1007/s10551-016-3330-4

Hussler, Caroline; Muller, Paul; Rondé, Patrick (2011). "Is diversity in Delphi panelist groups useful? Evidence from a French forecasting exercise on the future of nuclear energy". Technological forecasting and social change, v. 78, n. 9, pp. 1642-1653.

https://doi.org/10.1016/j.techfore.2011.07.008 
Illia, Laura; Romenti, Stefania; Rodríguez-Cánovas, Belén; Murtarelli, Grazia; Carroll, Craig E. (2017). “Exploring corporations' dialogue about CSR in the digital era". Journal of business ethics, v. 146, pp. 39-58.

https://doi.org/10.1007/s10551-015-2924-6

Jiang, Weiyan; Wong, Johnny (2016). "Key activity areas of corporate social responsibility (CSR) in the construction industry: a study of China". Journal of cleaner production, v. 113, pp. 850-860.

https://doi.org/10.1016/j.jclepro.2015.10.093

Kendall, Julie E.; Kendall, Kenneth E.; Smithson, Steve; Angell, lan O. (1992). "SEER: A divergent methodology applied to forecasting the future roles of the systems analyst". Human systems management, v. 11, n. 3, pp. 123-135.

https://content.iospress.com/articles/human-systems-management/hsm11-3-03

Kollat, Jana; Farache, Francisca (2017). “Achieving consumer trust on Twitter via CSR communication”. Journal of consumer marketing, v. 34, n. 6, pp. 505-514.

https://doi.org/10.1108/JCM-03-2017-2127

Kuokkanen, Henri; Sun, William (2019). “Companies, meet ethical consumers: Strategic CSR management to impact consumer choice". Journal of business ethics.

https://doi.org/10.1007/s10551-019-04145-4

Landeta, Jon (2006). "Current validity of the Delphi method in social sciences". Technological forecasting and social change, v. 73, n. 5, pp. 467-482.

https://doi.org/10.1016/j.techfore.2005.09.002

Lock, Irina; Seele, Peter (2016). "CSR governance and departmental organization: a typology of best practices". Corporate governance, v. 16, n. 1, pp. 211-230.

https://doi.org/10.1108/CG-01-2015-0010

Maignan, Isabelle; Ferrell, O. C.; Ferrell, Linda (2005). "A stakeholder model for implementing social responsibility in marketing". European journal of marketing, v. 39, n. 9/10, pp. 956-977.

https://doi.org/10.1108/03090560510610662

Michelon, Giovanna; Boesso, Giacomo; Kumar, Kamalesh (2013). "Examining the link between strategic corporate social responsibility and company performance: An analysis of the best corporate citizens". Corporate social responsibility and environmental management, v. 20, n. 2, pp. 81-94.

https://doi.org/10.1002/csr.1278

Monfort, Abel; Villagra, Nuria; López-Vázquez, Belén (2019). “Exploring stakeholders' dialogue and corporate social responsibility (CSR) on Twitter". El profesional de la información, v. 28, n. 5, e280513.

https://doi.org/10.3145/epi.2019.sep.13

Navarro-García, Fernando (2012). Responsabilidad social corporativa: Teoría y práctica. Madrid: Esic Editorial. ISBN: 978 8473568241

Niño-Benavides, Teresa-del-Pilar; Cortés-Cortés, María-Isabel (2018). “Comunicación estratégica y responsabilidad social empresarial, escenarios y potencialidades en creación de capital social: una revisión de la literatura". Prisma social, n. 22, pp. 127-158.

https://revistaprismasocial.es/article/view/2570

Okoli, Chitu; Pawlowski, Suzzane D. (2004). "The Delphi method as a research tool: An example, design considerations and applications". Information and management, v. 42, n. 1, pp. 15-29.

https://doi.org/10.1016/j.im.2003.11.002

Osagie, Eghe R.; Wesselink, Renate; Blok, Vincent; Lans, Thomas; Mulder, Martin (2016). "Individual competencies for corporate social responsibility: A literature and practice perspective". Journal of business ethics, v. 135, pp. $233-252$. https://doi.org/10.1007/s10551-014-2469-0

Rodrigo, Pablo; Aqueveque, Claudio; Duran, Ignacio J. (2019). “Do employees value strategic CSR? A tale of affective organizational commitment and its underlying mechanisms". Business ethics: A European review, v. 28, n. 4, pp. 459-475. https://doi.org/10.1111/beer.12227

Rowe, Gene; Wright, George (2001). "Expert opinions in forecasting: the role of the Delphi technique”. In: Armstrong, J. Scott. Principles of forecasting: A handbook for researchers and practitioners. Boston: Kluwer Academic Publishers, pp. 125-144. ISBN: 0792379306

Ruggiero, Pasquale; Cupertino, Sebastiano (2018). “CSR strategic approach, financial resources and corporate social performance: The mediating effect of innovation". Sustainability, v. 10, n. 10, 3611.

https://doi.org/10.3390/su10103611 
Saxton, Gregory D.; Ren, Charlotte; Guo, Chao (2020). "Responding to diffused stakeholders on social media: Connective power and firm reactions to CSR-related Twitter messages". Journal of business ethics.

https://doi.org/10.1007/s10551-020-04472-x

Sebastián-Morillas, Ana; Martín-Soladana, Irene; Clemente-Mediavilla, Jorge (2020). "Relevance of the insights in the strategic and creative process of advertising campaigns". Estudios sobre el mensaje periodístico, v. 26, n. 1, pp. 339-348. https://doi.org/10.5209/esmp.66570

Skulmoski, Gregory J.; Hartman, Francis T.; Krahn, Jennifer (2007). "The Delphi method for graduate research". Journal of information technology education, v. 6, pp. 1-21.

https://doi.org/10.28945/199

Villagra, Nuria; López, Belén; Monfort, Abel (2015). “The management of intangibles and corporate branding: Has anything changed in the relationship between business and society?" Revista latina de comunicación social, n. 70, pp. 793-812.

https://doi.org/10.4185/RLCS-2015-1072en

Von-der-Gracht, Heiko A. (2012). "Consensus measurement in Delphi studies. Review and implications for future quality assurance". Technological forecasting and social change, v. 79, n. 8, pp. 1525-1536.

https://doi.org/10.1016/j.techfore.2012.04.013

Weinreb Group (2011). CSO back story: How chief sustainability officers reached the c-suite. Weinreb Group. https://www.csrwire.com/press_releases/32989-cso-back-story-how-chief-sustainability-officers-reached-the-c-suite

Xifra, Jordi (2020). “Comunicación corporativa, relaciones públicas y gestión del riesgo reputacional en tiempos del Covid-19". Profesional de la información, v. 29, n. 2, e290220.

https://doi.org/10.3145/epi.2020.mar.20

\section{Inforảrea}

\section{Ayudamos a tu organización en la transformación digital y el gobierno de la información}

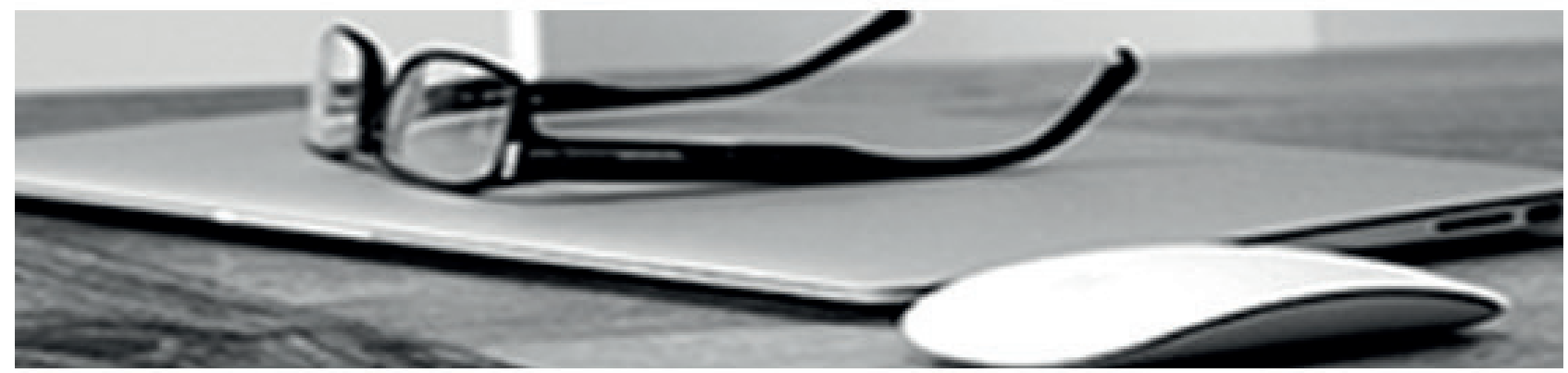

* Consultoría estratégica en gestión y gobierno de la información

* Gestión documental y "records management"

* Gestión de contenidos, intranets corporativas y entornos de colaboración

* Estudios especializados

Clientes satisfechos, cientos de empresas nacionales e internacionales y más de 30 años de experiencia son la mejor garantía de nuestra reputación. 